\title{
Györffy György kartográfiai munkássága
}

\author{
Györffy János - Zentai László
}

DOI: $10.30921 / G K .73 .2021 .1 .2$

Absztrakt: Györffy György, a neves középkori történész az egykorú írott forrásokból kiindulva, a rokon tudományágak eredményein túl a földrajzi szempontot hangsúlyosan felhasználta vizsgálataihoz. Számos szemléltetô térképet tervezett könyveihez, tanulmányaihoz, a Kartográfiai Vállalat történelmi atlaszához. Másrészt térképen ábrázolt történelmi jelenségeket a térbeli összefüggések feltárásához, amiböl újszerü következtetéseket vont le. Ehhez felhasználta az Árpád-és kora Anjou-kori oklevelek földrajzi adatait tartalmazó adatbázisát, amelyen „Az Árpád-kori Magyarország történeti földrajza” címü munkája alapult.

Abstract: György Györffy, the renowned medieval historian used the geographical aspect in his research based on contemporary written sources in addition to the results of related disciplines. He designed several illustrative maps for his books, his scientific papers and for the historical atlas of the Cartographia Company. On the other hand, he mapped historical phenomena to explore spatial relationships, from which he drew novel conclusions. For this purpose, he used the database of geographical data of the Árpádian and early Anjou-era diplomas, on which his work entitled "A historical geography of Hungary in the Arpádian period" was based.

Kulcsszavak: Árpád-kor, történelmi térképek, történelmi atlasz, történeti földrajz, Anonymus

Keywords: Kingdom of Hungary (Árpádian period), historical map, historical atlas, historical geography, Anonymus

2020. december 19-én volt húsz éve, hogy elhunyt Györffy György Széchenyi- és Herder-díjas tudós, aki a köztudatban történészként él, éspedig mint a honfoglalás, az Árpád-kor, kivált pedig Szent István munkálkodásának avatott kutatója. Életmúvében ugyanakkor fontos szerepet játszottak a térképek, amelyeket múveiben nem csak a történelmi jelenségek szemléltetésére, hanem összefüggések felfedezésére is használta, és a történelmi atlaszok szerkesztése terén is letette a névjegyét.

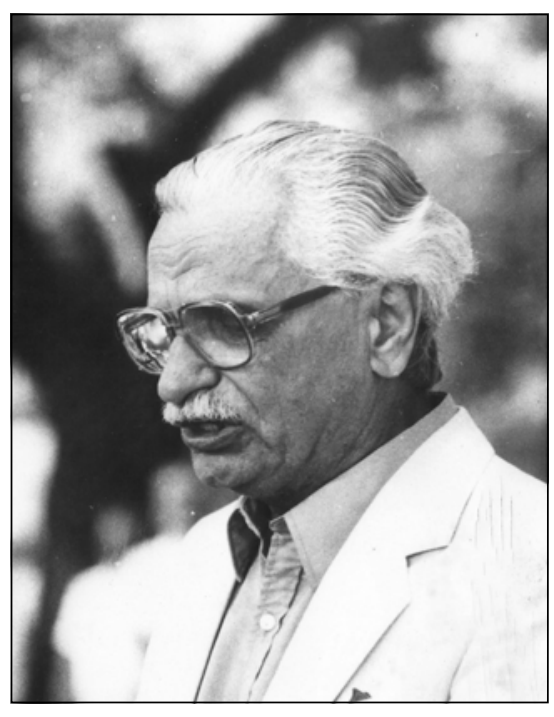

Györffy György

Életútjának a térképekhez való kapcsolódását determinálta, hogy gyerekkorától érdeklődéssel forgathatta apja, Györffy István néprajztudós könyvés térképtárának darabjait, amelyek

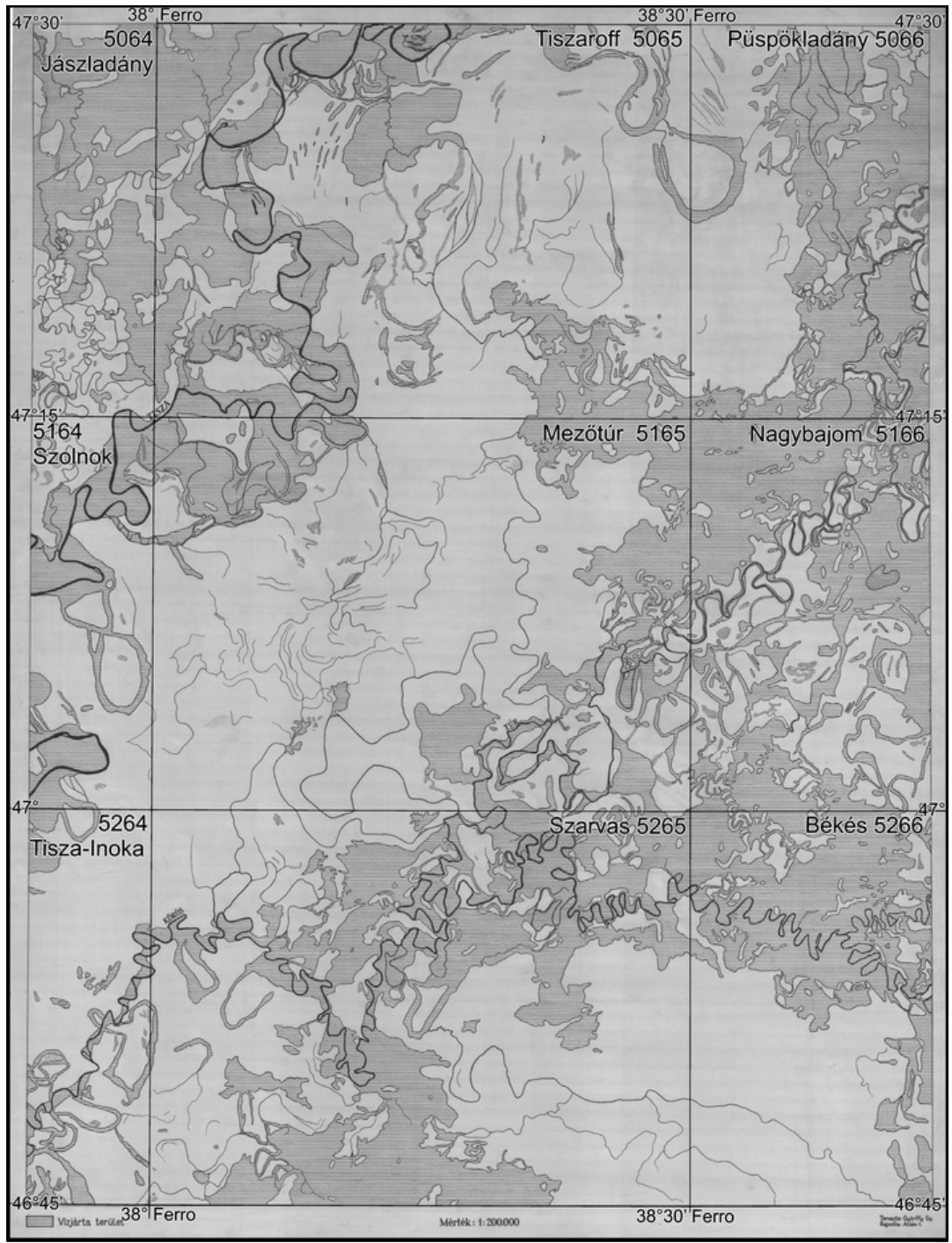

1. ábra. A Nagykunság és tágabb környékének vizjárta területei a folyószabályozás elôtt az alaptérképként használt 1:75 ezres topográfiai térképszelvények határaival (Györffy György nyomán, eredeti méretarány 1:200 000) 
között sok más térkép mellett ott volt a pl. a III. katonai felmérés 1:75 000 és 1:200 000 méretarányú térképszelvényeinek a Kárpát-medencét bemutató, szinte teljes sorozata. Györffy István 1939-ben bekövetkezett váratlan halála után fia a torzóban maradt kutatásokat kiegészítette és publikálta (Györffy I. 1942, 1943), amelynek során részletes áttekintést kapott az etnikai és településföldrajzi térképek sokaságát eredményezó életmúrôl.

1935-ben iratkozott be a Pázmány Péter Tudományegyetem földrajz-történelem szakára.

Egyetemi éveiben eleinte inkább a földrajzhoz vonzódott, és csak késôbb fordult a történelem felé, amelyre a térben lezajló és térképpel szemléltetendô folyamatként tekintett. Már hallgató korától készített térképmellékleteket könyvekhez és tanulmányokhoz (Harsányi 1938, Györffy Gy. 1939, 1941).

1942-ben behívták katonának. 1943-44-ben karpaszományos ôrmesterként a M. Kir. Honvéd Térképészeti Intézet vízrajzi szakosztályán dolgozott térképrajzolóként, majd a földrajzi osztályon volt beosztott (BallaHrenkó 2006). Beiskolázták térképész tiszti tanfolyamra, ami a front közeledtével félbeszakadt. Az intézet nyugatra településében egészségügyi okokból nem vett részt, az ostromot a Nemzeti Múzeum pincéjében vészelte át.

1945-ben megszervezte és igazgatóként vezette a Teleki Pál Tudományos Intézet (1948-tól Kelet-európai Tudományos Intézet) Néptudományi Intézetét. Egy ott végzett kutatás keretében Karcag környékén vizsgálta a Földmúvelésügyi Minisztérium Vízrajzi Intézetében 1938-ban készült, a Kárpát-medence vízborította és árvízjárta területeinek az ármentesítô és lecsapoló munkálatok megkezdése elốtti állapotát ábrázoló ún. pocsolyatérkép megbízhatóságát (Györffy Gy. 2006, 1991). Ennek során - XVIII. századi térképek, ármentesítő felvételek és talajtérképek alapján - 1:200 ezres méretarányban elkészítette a Nagykunság és tágabb környékének régi vízrajzi térképét (1. ábra).

Ezt összevetve a „pocsolyatérképpel" azt találta, hogy azon a valóságosnál nagyobbnak ábrázolták a vízzel elárasztott területet. A térképhez felhasznált alapanyagok - az árvízmentesítố társulatok térképei ugyanis nem a régi állapotot, hanem a gátak közé szorított vízfolyások magasabb vízállása alapján megállapított adóztatható területet tüntették fel.

\section{A történeti földrajzi adatbázis kialakítása}

A Néptudományi Intézet 4231/1949. számú minisztertanácsi rendelettel történt megszüntetése után az MTA Történettudományi Intézete munkatársaként folytatta kutatásait. 1950ben kezdett bele nagy munkájába, az Árpád-kori Magyarország történeti földrajzába. Az elsô évek (1956ig) az anyaggyújtéssel teltek, ami az
Árpád-kori és kora Anjou-kori oklevelekben lévố földrajzi vonatkozású adatok kigyújtését jelentette. A munka felölelte a IX. századtól az 1301-ig tartó idószak mintegy 10000 oklevelét, amihez az Anjou-kor elsô három évtizedének további 10000 oklevele járult, magába foglalva a pápai tizedlajstrom 1332-37 között kelt okleveleit. Az anyaggyújtésben számos diplomatikával (középkori oklevéltannal) foglalkozó munkatárs vett részt, köztük nagy tudású, a tudományos életbôl eltávolított személyek (pl. Kumorovitz L. Bernát). A kigyújtött mintegy 80000 adat feldolgozása az ábécébe sorolt vármegyék szerinti bontásban történt.

A szerzô életében négy kötet jelent meg (Györffy Gy. 1963, 1987A, 1987B, 1998), amelyekben összesen

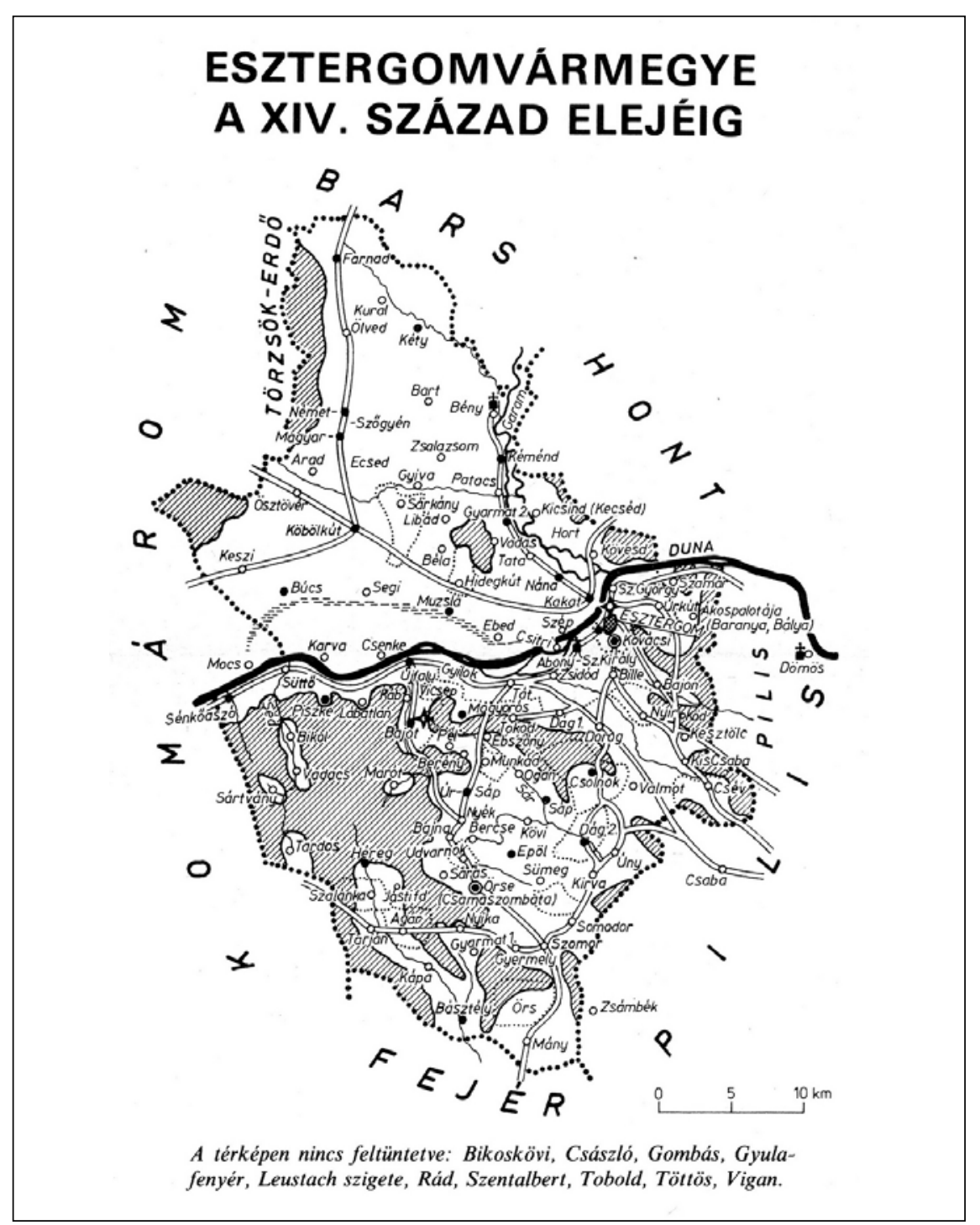

2. ábra. Esztergom vármegye térképe az Árpád-kori Magyarország történeti földrajzából (Györffy György nyomán) 
38 vármegye található, ezeket 37 térkép mutatja be. A térképek és városalaprajzok zömét Schöberl Magda grafikus, Tiderle Lajos térképész és Nagy Béla térképész készítette, rajtuk kívül Anka Magdolna, Bartos-Elekes Zsombor, Gombocz András és Györffy János múködött közre (2. ábra).

A cédulák rendszerezését és ellenőrzését Györffy György maga végezte, ennek során a teljes vonatkozó oklevélállományt áttekintette és részletesen megismerte (Solymosi 2017). Így egy rendkívül értékes adatbázis birtokába jutott, amelynek milliós nagyságrendú elemi adata (Zsoldos 2001) nagyszámú földrajzi vonatkozást tartalmaz. A további munkásságában alkotó módon kezelte ezeket az adatokat, a földrajzi nevekre, különösen a településnevekre alapozva új összefüggéseket fedezett fel és bontott ki. Ezt jól mutatja be két tanulmánya, amelyekben a jeles Árpád-kori „névtelen jegyző”, Anonymus személyével és krónikájának hitelességével foglalkozik.

\section{Adalékok Anonymus személyéhez annak földrajzi tájékozottsága alapján}

Anonymus Gesta Hungarorum címú múvében számos Kárpát-medencei objektum (hegy, folyóvíz, királyi vagy ispáni vár, egyházi központ, falu, nagybirtok) van megemlítve. Györffy György egy munkájában (Györffy Gy. 1970B) abból indult ki, hogy egy földrajzi objektum megemlítését az objektum fontosságától függốen eltérốen kell értékelni: jelentôs helyeket bárki ismerhet, viszont a jelentéktelenebb helyek ismerete hosszabb ott-tartózkodás során kialakult járatosságot feltételez. Úgy vitte tehát térképre ezeket az objektumokat, hogy három kategóriájukat állapította meg:

1. Országos hírú helyek, melyekrôl a kancelláriai írnoknak tudomása volt - ezeket kis méretú jellel jelölte.

2. Helyek, amelyek ismerete legalább rövidebb ott-tartózkodást tételez fel - ezeket közepes nagyságú jelekkel adta meg.

3. Jelentéktelen helyek, amelyek csak huzamos ott-tartózkodással ismerhetôk meg (határnév; egy falu határán belül fekvố hegy vagy domb; 10 km-nél rövidebb folyóvíz; pontosan körülírt birtok) ezeket ábrázolta a legnagyobb jellel.

A térkép a rövidítések jegyzékével az alábbiakban látható (3. ábra).

A térkép alapján „P. dictus magister" - ahogy Anonymus a múvében magát nevezte - nem mutat tájékozottságot a más érvek alapján valószínúsíthetố egyházi méltóságok állomáshelyén, így nem lehetett sem Péter esztergomi prépost, sem Péter gyôri püspök, és az egri püspökség birtokain való jártasság is cáfolható. Viszont Buda környékét nagyon alaposan ismerte a névtelen szerzó. III. Béla és utóda, Imre király uralkodása idejéból P-vel kezdôdố budai prépostot a források nem említenek, bár 1186 és 1211 között fel sem jegyezték a budai prépostok nevét. Györffy György véleménye szerint egy ebben az időben ténykedô, ismeretlen nevú budai prépost lehetett Anonymus. (Ezt megerôsítheti egy

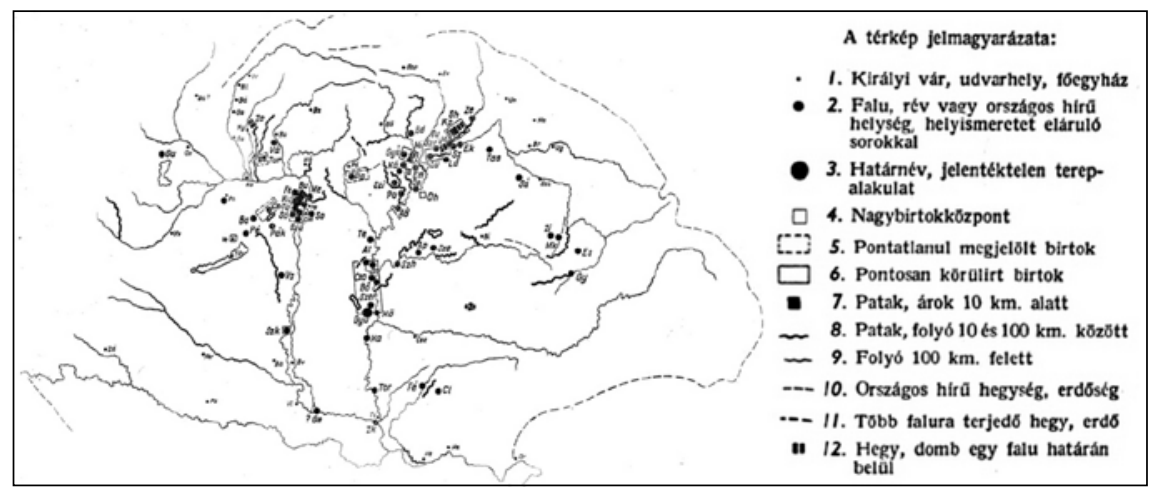

3. ábra. Anonymus helyismerete (Györffy György nyomán) néhány évtizeddel késôbbi, 1124-re datált hamisított oklevél, amelyben megemlítenek egy Péter nevú budai prépostot, mint a királyi oklevél megpecsételőjét.) A névtelen jegyzô továbbá, amint azt a fenti térkép is demonstrálja, igen jó helyismerettel rendelkezett a Felsô-Tisza vidékén (Dél-Zemplénben és Dél-Borsodban is), ami több kutató szerint a származási helyére utalhat.

\section{Anonymus leírásának hitelessége a Kárpát- medence honfoglalás elótti uralmi viszonyairól}

Anonymus az 1200 körül keletkezett krónikájában többek között leírást ad a 300 évvel korábban végbement honfoglalás és a megtelepedés eseményeirôl, és ennek során többször ír a Kárpát-medence IX. századi államalakulatairól és meghódításukról. Ezek a leírások napjainkig sok kombinációnak és elméletnek szolgálnak alapul. Györffy György egy másik dolgozatában (Györffy Gy. 1965) összehasonlítás céljából egy-egy térképvázlaton ábrázolja az egykorú forrásokból kikövetkeztethető uralmi rendet (4. ábra) és az anonymusi államocskákat (5. ábra).

Jól látható, hogy az általuk sugallt kép köszönó viszonyban sincs a hiteles egykorú adatokból kikövetkeztethetô uralmi helyzettel.

Anonymus tájékozódhatott fơúri kortársaitól azok honfoglaló ôseinek nevérôl és olykor birtokaik földrajzi elhelyezkedésérôl is. Ebből kiindulva és más adatokat is figyelembe véve nagyjából meghatározhatók a magyar fốemberek Szent István fellépése elôtti uralmi körzetei, amiből egy újabb térképvázlat készült (6. ábra). Ha ennek tartalmát összevetjük a IX. századi anonymusi államalakulatokkal, akkor egy hasonló mintázatot fedezhetünk fel.

Györffy György kifejti, és okleveles, nyelvészeti és településneveken alapuló forráskritikai érvekkel alátámasztja, hogy Anonymus az államalapításhoz köthetô vagy azt megelôzô magyar belvillongásokat vetítette vissza a honfoglalás hadi eseményeibe. 


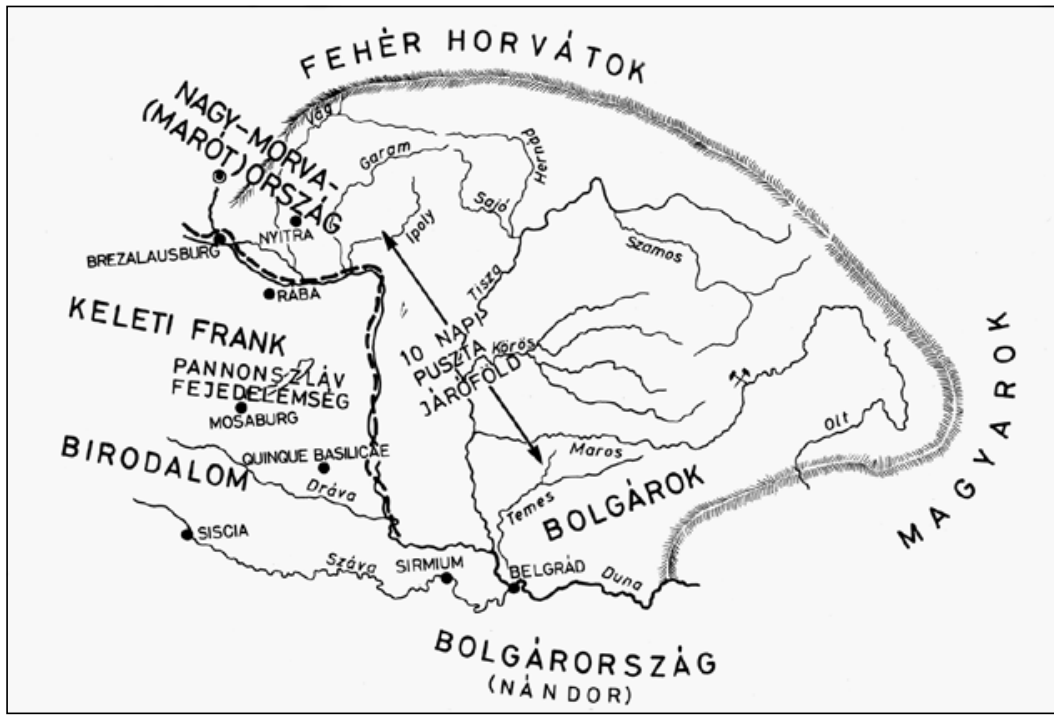

4. ábra. a Kárpát-medence államai a IX. század végén egykorú adatok szerint (Györffy György nyomán)

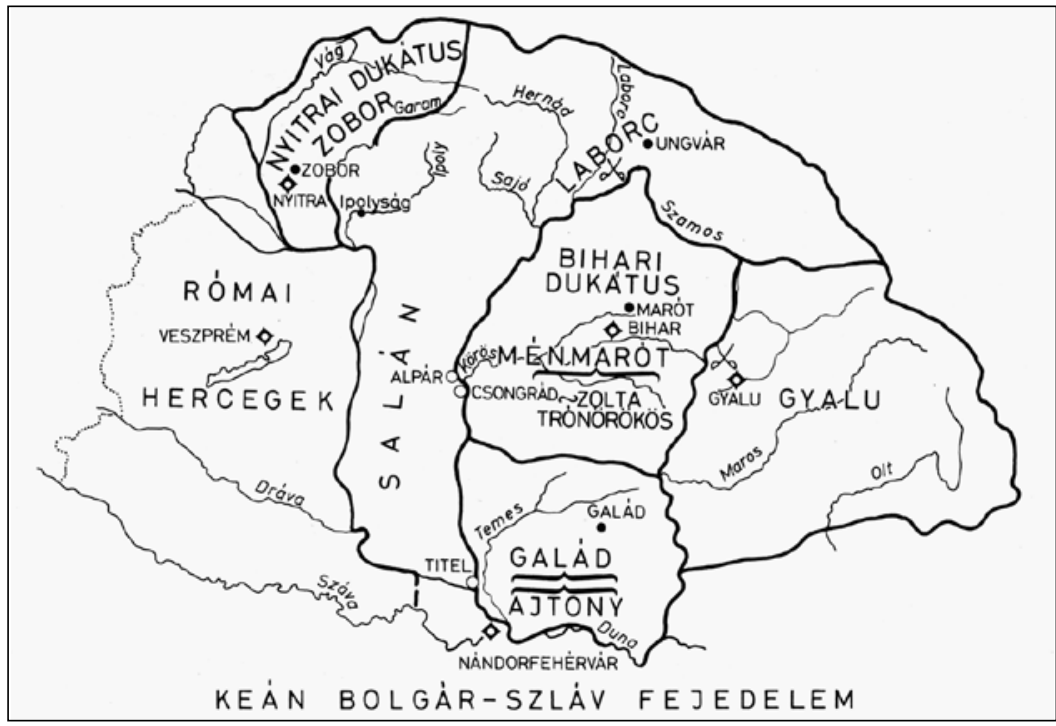

5. ábra. Anonymus elképzelése a Kárpát-medence IX. század végi országairól (Györffy György nyomán)

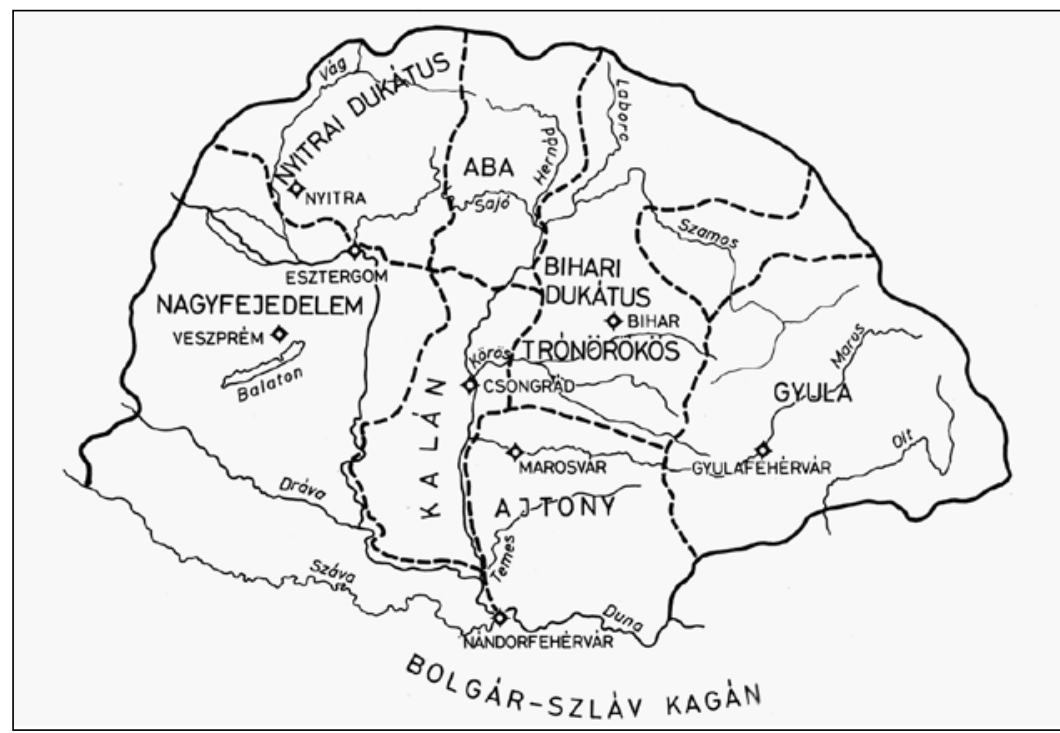

6. ábra. Uralmi körzetek Magyarországon i. sz. 1000 körül (Györffy György nyomán)
Folyómenti nomadizálás a honfoglalás utáni Kárpát-medencében

A Mongol Birodalomba követként küldött XIII. századi szerzetes utazók az itáliai Plano Carpini Johannes és a flandriai francia Rubruk Willelmus - említést tesznek arról, hogy a mongol főemberek a Kelet-európai síkság Fekete-tengerbe ömlő nagy folyói mentén tartottak fent egy nyári szállást a torkolat közelében, valamint egy téli szállást a folyók északi felső szakaszán (7. ábra), és e kettốt váltva vonultak (transzhumáltak) tavasszal és ősszel a folyó mentén kíséretükkel, állataikkal. Györffy György ennek analógiájára egy hasonló modellt állított fel a Kárpát-medencébe költözött magyar vezérek, nemzetségfők birtokainak elhelyezkedésére, ami megmagyarázza a méltóságokról elnevezett földrajzi helyek valamilyen, általában térképen jól felismerhetô szabályszerúséget követô lokációját, pl. kettôs vagy többes elôfordulását egy-egy folyó mentén.

Egy ilyen helynévrendszer mutatható ki pl. a Sebes-, Fekete- és FehérKörös mentén, ahol az Anonymus Gestájában is elóforduló X. századi Ôsi nevú vezérrốl elnevezett hét település található (8. ábra).

Györffy 19 térképen mutatta be a különbözố méltóságok folyó menti szállásváltását az elméletét kifejtô tanulmányában (Györffy Gy. 1970A). Nézete szerint pl. a kettôs fejedelemségnek megfelelően lett felosztva a Duna magyarországi szakasza, amely mentén Aquincumtól a Csallóközig Kurszán vezér, a Csepel-szigettől a Pécs melletti Árpád faluig pedig Árpád vezér nomadizált (9. ábra).

További vezérek - pl. Tétény, Szabolcs - (9. ábra) és Árpádleszármazottak neve is felfedezhetô a korai oklevelekben említett Duna menti települések nevében. Utóbbi utalhat a nomadizálási útvonal öröklésére. Feltételezhetôk további útvonalak pl. a Dunántúlon, a Sárvíz és a Kapos mellékén Fajsz, Tormás és Tarhos nevú települések között, vagy Erdélyben, a Maros, a Küküllôk és az Olt mentén Ajtonyról, Zsomborról és Bojáról elnevezett helyek között. 


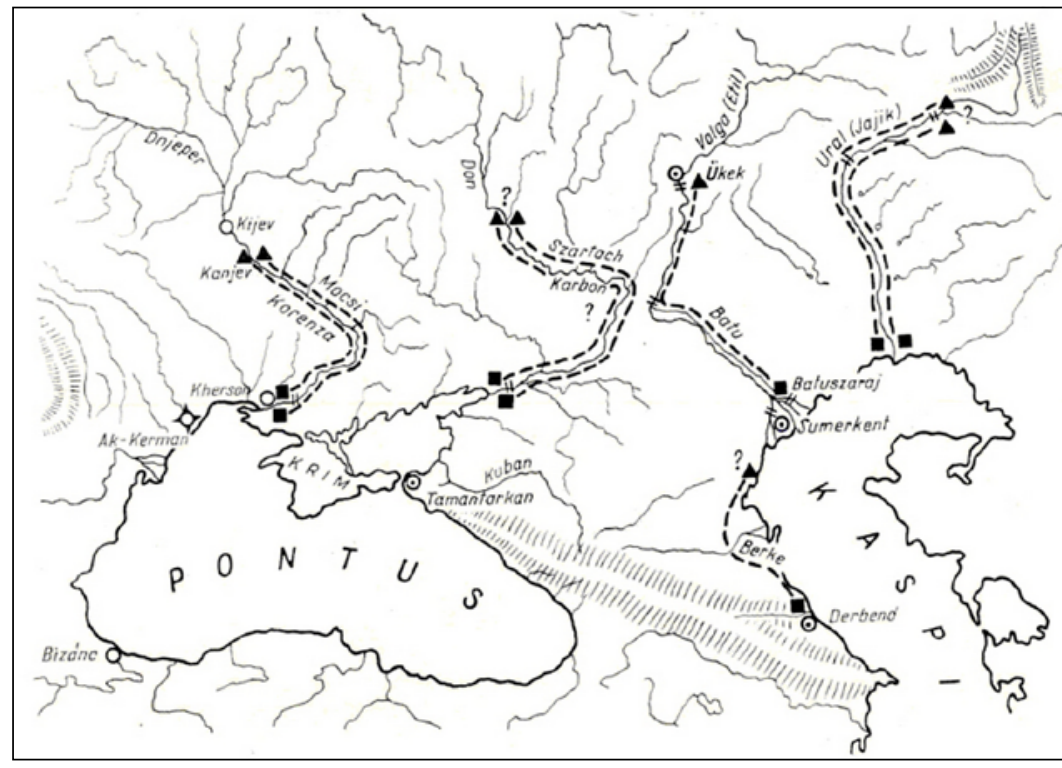

7. ábra. Mongol fôemberek téli és nyári szálláspárjai Kipcsakban (Györffy György nyomán)

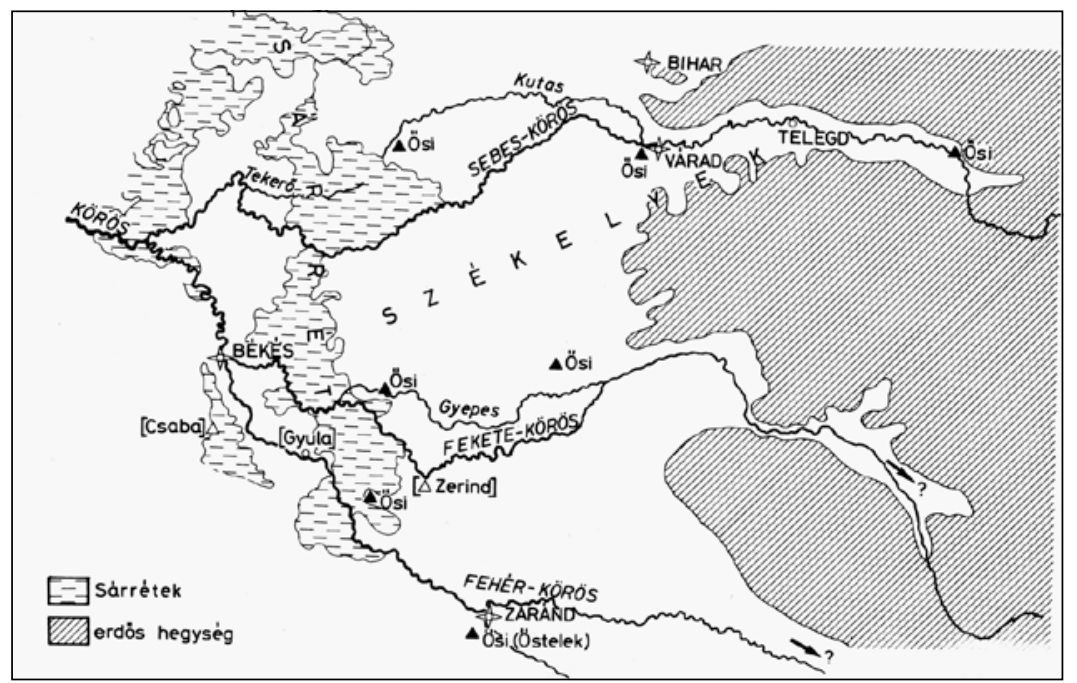

8. ábra. Ôse (Ốsi) vezér nevét viselô helységnevek a Dunától keletre (Györffy György nyomán)

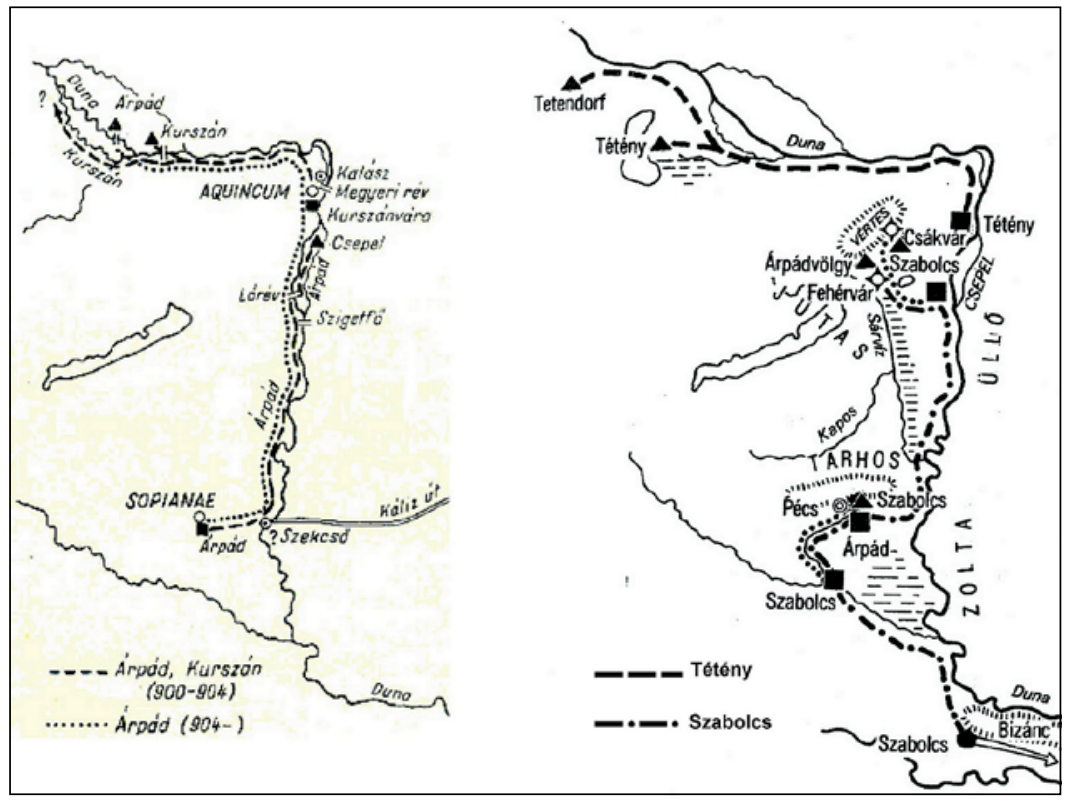

9. ábra. Kurszán és Árpád fejedelmek, valamint Tétény és Szabolcs vezérek partvonalai (Györffy György nyomán)
Ezek a földrajzi nevek elhelyezkedésére alapozott nézetek, sôt általában a térbeli összefüggésekből levonható történelmi következtetések (Gábris 2019) nehezen elfogadhatók a forrásokat abszolutizáló kutatók számára, esetünkben azonban nem kapunk tôlük alternatív magyarázatot a fentiekben összefoglalt jelenségekre.

Az István király és múve címú összefoglaló munkában (Györffy Gy. 1977) 48 térkép szemléltet korabeli földrajzi kapcsolatokat. A Magyarország története címú nagyszabású akadémiai vállalkozásban a Györffy által megírt fejezetek (Györffy Gy. 1984) 18 térképet tartalmaznak (10. ábra). Ezeket mind a szerző tervezte.

\section{Történelmi atlasz szerkesztése}

A Múvelôdésügyi Minisztérium megbízásából a középiskolák számára készítendô Történelmi Atlasz munkálatai az 1954-ben létrejött Kartográfiai Vállalatnál rögtön az alapítás után megkezdôdtek (Hidas-Turcsán 2006). A munkába bevonták az akkori vezetô történész és térképész gárda exponenseit. A Kartográfiai Vállalat szerkesztôbizottságának elnöke (az 1955-ben a Szovjetunióból hazatért) Radó Sándor, a Mezôgazdasági és Élelmezésügyi Minisztériumon belül múködô Országos Földügyi és Térképészeti Hivatal térképészeti fôosztályának vezetôje lett. A Történelmi Atlasz szakmai szerkesztôbizottságában Györffy György mellett tag volt Pamlényi Ervin (Magyar Tudományos Akadémia Történettudományi Intézet) a legújabb kori történelemhez kapcsolódó térképek szakértôjeként. Csatáry Mária (Oktatási Minisztérium) a pedagógiai szempontokat érvényesítette, míg a Kartográfiai Vállalat részérôl Bognár Gábor és Takács József képviselte a térképészszakmát.

A hagyatékban fennmaradt, a Kartográfiai Vállalattól kapott levelek (jegyzôkönyvek, szerzôdések, meghívók) alapján megállapítható, hogy 1955-56-ban már érdemi munka folyt. Györffy György 11 térképet tervezett az atlasz számára 
(térképrészletet lásd a címlapon), az egyik oldalt pedig átdolgozta és kibôvítette, és számos további térkép lektorálásában is közremúködött.

Az atlaszt 1959-ben nyomtatták ki, a bemutatópéldányokat ez év augusztusában küldték ki a szerzóknek. Györffy György személyes közlése szerint az atlasz szerkesztésének munkáit döntô részben Radó Sándorral ketten végezték, minthogy - a Kartográfiai Vállalat munkatársait leszámítva - térképszerkesztôi gyakorlatuk nekik volt. Hangsúlyozta Radó Sándor élénk történeti érdeklôdését, ami különösen a magyar történelem iránt nyilvánult meg, és ami hozzájárult a munka sikeréhez.

A kor színvonalán elkészített, kinyomtatott és 1959-ben kiadott atlasz példányait röviddel a forgalomba kerülése után visszavonták és némely források (Hidas-Turcsán 2006) szerint bezúzták, mert egyes szomszédos országok - a Szovjetunió, Románia, Csehszlovákia - hivatalos úton tiltakoztak az atlasz szemlélete ellen, és konkrét kifogásokat is tettek. A Múvelôdésügyi Minisztérium ennek szellemében levélben utasította a szerkesztôbizottságot, melyben pontonként felsorolta a szükséges változtatásokat. A tennivalók a szerkesztôbizottság 1960. október 3-i ülésén jutottak az illetékesek tudomására. A minisztérium álláspontját Pamlényi Ervin képviselte, Radó Sándor és Györffy György távollétével fejezte ki egyet nem értését. A jegyzőkönyv szerint Mészáros György igazgató így zárta le az ügyet:

„A vállalat kötelezónek tartja magára nézve a minisztériumtól írásban kapott változtatásokat ugyanazon formában végrehajtani, mint ahogyan az a levélben szerepel. Ez vonatkozik a pótlólag felvett térképlapokra is."

Az átalakítások végrehajtása után a második kiadás 1961-ben készült el. Györffy György a középkori részt illetố változtatásokat igen rossz néven vette, az utólag bekerült elemeket anakronisztikusnak tartotta.

A Kartográfiai Vállalat a hatvanas évek elején a Történelmi Atlasz térképeire támaszkodva, de azokat akár lényegesen is átdolgozva iskolai falitérképek sorozatát jelentette meg. Györffy György szerzôsége a dokumentumokból hat falitérkép tervezésében állapítható meg. Térképészeti tevékenysége elismeréseképpen a tudós a Magyar Tudományos Akadémia Földrajzi Bizottságának 1965-ben megalakult Térképtudományi Albizottságában tag, majd a még ez évben megalakult Térképtörténeti Munkabizottságban társelnök lett.

Igyekezett beszerezni a más országokban kiadott történelmi atlaszokat, és folyamatosan tanulmányozta azokat, mind tartalmi, mind kartográfiai szempontból. Felfigyelt az atlaszokban megmutatkozó azon törekvésekre, amelyek célja fóként a XX. századi államalakulatok és országhatárok történeti igazolása volt. Arra is rámutatott, hogy ezek a tévtanok, amelyek többnyire egy-egy rosszul értelmezett vagy hamis történelmi adaton alapulnak, elterjedtek a nemzetközi tudományos életben, és onnan idônként már magyar atlaszokba is visszakerültek. Úgy vélte, és ezt többször szóvá tette, hogy a Történettudományi Intézetnek egyik feladata éppen az ilyen történelemhamisítások kimutatása és azok megcáfolása volna.

A Történettudományi Intézetben a nyolcvanas évektôl dolgoztak egy nagy történelmi atlasz elkészítésén. Ennek elôsegítésére a tanácsadóként (késôbb akadémiai levelezó tagként majd akadémikusként) közremúködố Györffy György 1988 decemberében elôadást tartott, amely Kiss Lajos nyelvész tartalmas hozzászólásával együtt sajtó alá rendezve nyomtatásban is megjelent (Györffy Gy. 1991). Ebben áttekintést adott a világban megjelent számos történelmi atlaszról, az azokban alkalmazott kartográfiai megoldásokról, a térképek és a kísérố szöveg arányáról. Hangsúlyozta, hogy a jó atlasz legfontosabb jellemzóje tartalmi szempontból a hitelesség, amit adott esetben egy-egy facsimile okmány vagy pecsét bemutatásával is érdemes alátámasztani.

Fontosnak tart egy térképtörténeti bevezetést, ami „az ókori térképektôl elvezetne napjaink térképeiig", és amihez konkrét térképeket javasol, a végén a Közép-Duna-medence múholdas felvételével. Felsorol még közép- és kelet-európai országokban készült atlaszokból egy sor, elfogult szemléletet tükrözó téves adatot, ábrázolást, elsôsorban magyar szempontot tartva szem elôtt, de

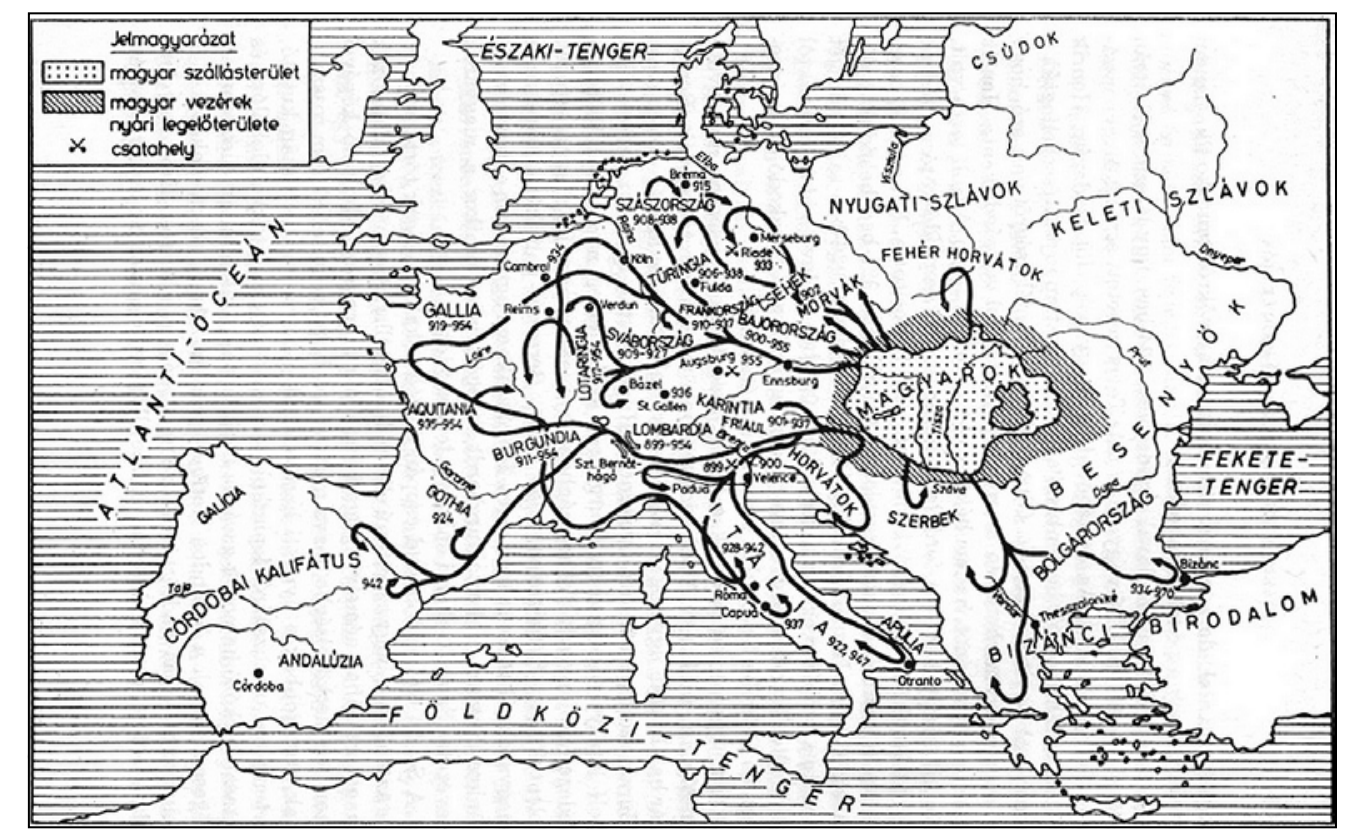

10. ábra. A kalandozások (Györffy György nyomán) 
néhány más kirívó ferdítést is megemlít. Ezek ellen leghatásosabbnak a jó forráskiadványok megjelentetését tekinti, amelyekben a táblázatba foglalt adatok mellé a szemléletes térképi megjelenítést hangsúlyozza. Szorgalmazza a Kárpát-medence régi természetföldrajzi viszonyairól készült megalapozott térképek készítését, megemlítve itt a „pocsolyatérkép" megbízhatatlanságát, valamint a település- és népességtörténet térképekkel történô bemutatását. Ugyancsak foglalkozik az útviszonyok, az ipar, a közigazgatás és a szellemi kultúra hiteles térképi ábrázolásával.

A tartalmi kérdések mellett foglalkozott a kartográfiai megvalósítás kérdéseivel is. Itt a - kiállítás szépségével szemben - a jó áttekinthetôségre fekteti a hangsúlyt. „... sok színnel történô ábrázolás nem elsôrendú feltétele a térképek megértésének. Segíthet ugyan benne és széppé teheti a térképet, de nem döntő követelmény. Jacques Bertin... beszélgetésünk során határozottan a fekete-fehér ábrázolás mellett állt ki, azzal a megokolással, hogy a lényeget így erôteljesebben ki lehet fejezni..." - írja (10. ábra). (Györffy György az 1980-as években találkozott Jacques Bertinnel. A 2010-ben elhunyt Bertin, francia kartográfus és geográfus, a tematikus ábrázolás elméletének jeles kutatója 1967-ben írta meg máig nagy hatású könyvét a grafikus szemiológiáról - Bertin 1967.) Elhárította azt a munkahelyi felajánlást is, hogy a történeti földrajzi térképeit elkészítenék színes formában.

A Történettudományi Intézet nagy történelmi atlaszának elsô kötete 1995-ben megjelent, a második kötet is elkészült elektronikus formában, de már nem adták ki. Néhány kulcsfontosságú személy visszavonulásával a munka leállt, és egyelốre nincs kilátásban a folytatás.

\section{Összegzés}

A középkorral foglalkozó történészek elsôsorban az egykorú írott forrásokra, emellett a régészet, a nyelvészet és az egyetemes néprajz eredményeire támaszkodva idézik fel és helyezik összefüggésbe a régi korokat. Györffy György az oklevéltan nemzetközileg elismert tudósaként a felsoroltakon túl a földrajzi szempontot is belevitte a vizsgálatokba. Munkásságában a történelem a térben lejátszódó folyamatként jelenik meg. „Alig van történelmi jelenség, amelynek valami térbeli vonatkozása ne volna." - írja egyik cikkében (Györffy Gy. 1979). Hosszú élete során mind a történelmi térképek elméletében, mind a szakterületéhez tartozó történelmi témák térképezésében maradandót alkotott. Folyamatban van a család, az MFTTT és a Magyar Természettudományi Társulat nevében egy emléktábla állítása azon a házon, amelyben a 2000-ben elhunyt Györffy György lakott.

\section{Irodalom}

Balla J. - Hrenkó P. 2006. A magyar katonai térképészet története III. rész, Személyi kataszter. HM Térképészeti Kht., Budapest.

Bertin, Jacques 1967. Sémiologie graphique. Mouton/Gauthier-Villars, Paris, p. 431

Gábris Gy. 2019. Névföldrajzi kutatások - egy családnév földrajzi és történelmi háttere. Földrajzi Közlemények 143. évf. 1. sz. pp. 35-54.

DOI: $10.32643 /$ fk.143.1.4

Györffy Gy. 1939. Besenyôk és magyarok. A Kőrösi Csoma Archívum 1. kieg kötet. Budapest, p. 106

Györffy Gy. 1941. A székelyek eredete és településük története. Erdély és népei (szerk.: Mályusz Elemér). Királyi Magyar Pázmány Péter Tudományegyetem Bölcsészeti Karának Magyarságtudományi Intézete Budapest, pp. 35-86.

Györffy Gy. 1963. Az Árpád-kori Magyarország történeti földrajza I. kötet. Akadémiai Kiadó, Budapest, p. 907

Györffy Gy. 1965. Honfoglalás elôtti népek és országok Anonymus Gesta Hungarorumában. Ethnographia 76. évf. 3. sz. pp. 411-434.

Györffy Gy. 1970A. A honfoglaló magyarok települési rendjérôl. Archeologiai Értesítô 97. évf. 2. sz. pp. 19-242.

Györffy Gy. 1970B. Anonymus Gesta Hungarorumának kora és hitelessége. Irodalomtörténeti Közlemények 74 . évf. 1. sz. pp. 1-13.

Györffy Gy. 1977. István király és múve Gondolat, Budapest p. 668

Györffy Gy. 1979. Történelem és földrajz kapcsolata: történeti földrajz. História 1. évf. 4. sz. pp. 30-31.

Györffy Gy. 1984. Magyarország története. Elốzmények és magyar történet 1242-ig. Akadémiai Kiadó, Budapest, pp. 575-1006.
Györffy Gy. 1987A. Az Árpád-kori Magyarország történeti földrajza II. kötet. Akadémiai Kiadó, Budapest, p. 646

Györffy Gy. 1987B. Az Árpád-kori Magyarország történeti földrajza III. kötet. Akadémiai Kiadó, Budapest, p. 568

Györffy Gy. 1991. Történelmi atlasz készítésének kérdéséhez. MTA Történettudományi Intézet, Budapest, p. 30

Györffy Gy. 1998. Az Árpád-kori Magyarország történeti földrajza IV. kötet. Akadémiai Kiadó, Budapest, p. 714

Györffy Gy. 2006. Györffy István és Györffy György térképészeti munkássága. Térképvilág. A Magyar Térképbarátok Társulata elsô negyedszázada (19812006). Magyar Térképbarátok Társulata Budapest, pp. 9-14

Györffy I. 1942. Magyar nép, magyar föld (szerk.: Györffy György). Turul, Budapest, p. 477 (13 befûzött térkép, 2 szöveg közti település-alaprajz)

Györffy I. 1943. Magyar falu, magyar ház (szerk.: Györffy György). Turul, Budapest, p. 231 (1 befúzött térkép, 8 légifelvétel, 11 szöveg közti település-alaprajz)

Harsányi A. 1938. A domonkosrend Magyarországon a reformáció elôtt. Debrecen, p. 351

Hidas G. - Turcsán Zs. 2006. From smash to the HUNDIDAC Prize. Story of a historical atlas for secondary schools. Térkép - tudomány. Térképtudományi Tanulmányok (Studia Cartologica) 13. (szerk.: Zentai L. - Györffy J. - Török Zs.) ELTE Térképtudományi és Geoinformatikai Tanszék, Budapest pp. 179-186

Solymosi L. 2017. Györffy György életútja. Elôadás, elhangzott: MTA Emlékkonferencia Györffy György születésének 100. évfordulójára 2017. november 23 .

Történelmi atlasz. Kartográfiai Vállalat, Budapest 1959. p. 33

Zsoldos A. 2001. Györffy György. Magyar Tudomány XLVII. kötet 5. sz. pp. 611-613.

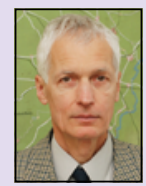

Dr. Györffy

János

ny. egyetemi

docens

ELTE Térképtudományi és Geoinformatikai Intézet gyorffy@caesar.elte.hu

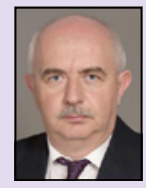

Dr. Zentai László egyetemi tanár intézetigazgató

ELTE Térképtudományi és Geoinformatikai Intézet laszlo.zentai@elte.hu 